\title{
Substrates and organic sources for Physalis peruviana L. seedling production
}

\section{Sustratos y fuentes orgánicas en la producción de plántulas de Physalis peruviana L.}

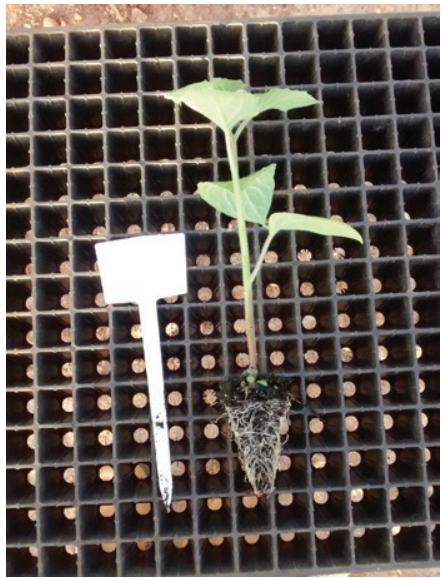

ANIELA PILAR CAMPOS DE MELO1,7

PAULO MARÇAL FERNANDES ${ }^{2}$

CARLOS DE MELO E SILVA-NETO ${ }^{3}$

ELI REGINA BARBOZA DE SOUZA²

RICARDO NEVES GUIMARÃES ${ }^{4}$

ARIANE CARLA CAMPOS DE MELO5

ALEXSANDER SELEGUINI ${ }^{6}$

\section{Physalis peruviana L. seedlings}

Photo: A.P.C. Melo

\begin{abstract}
The objective was to determine the effect of commercial substrates and organic sources on the production of cape gooseberry seedlings (Physalis peruviana L.). The design was completely randomized with a $2 \times 3$ factorial scheme using two commercial substrates (Carolina ${ }^{\circledR}$, Bioplant ${ }^{\circledR}$ ) and three organic sources (control, vermicompost enriched with yoorin thermophosphate and poultry manure) for seedling production. Adding poultry manure to commercial substrates negatively affects precocity and emergence. Carolina ${ }^{\circledR}$ is a suitable substrate for cape gooseberry seedling production without supplements using organic sources. Bioplant ${ }^{\circledR}$ behaves more like an emergence conditioner, requiring supplementation with organic sources (preferably vermicompost). Seedlings that are suitable for transplant can be obtained at 47 days after sowing.
\end{abstract}

Additional key words: exotic fruit; plant propagation; Solanaceae; boron; $\mathrm{C} / \mathrm{N}$ ratio.

Instituto Federal Goiano, Cristalina (Brazil). ORCID Melo, A.P.C.: 0000-0002-5687-5928

2 Universidade Federal de Goiás, Goiania (Brazil) ORCID Fernandes, P.M.: 0000-0003-3442-6539; ORCID Souza, E.R.B.: 0000-0001-6225-6122

3 Instituto Federal de Goiás, Goiás (Brazil). ORCID Silva-Neto, C.M.: 0000-0001-8624-3836

4 Centro Universitário Araguaia, Goiania (Brazil). ORCID Guimarães, R.N.: 0000-0003-0415-2645

5 Universidade Federal de Minas Gerais, Belo Horizonte (Brazil). ORCID Melo, A.C.C.: 0000-0003-1970-6356

6 Universidade Federal do Triângulo Mineiro, Iturama (Brazil). ORCID Seleguini, A.: 0000-0002-5762-9278

7 Corresponding author. aniela.pilar@ifgoiano.edu.br 


\section{RESUMEN}

El objetivo fue determinar el efecto de los sustratos comerciales y las fuentes orgánicas en la producción de plántulas de uchuva (Physalis peruviana L.). El diseño fue completamente aleatorizado, en un esquema factorial de $2 \times 3$, con dos sustratos comerciales la producción de plántulas (Carolina ${ }^{\circledR}$, Bioplant ${ }^{\circledR}$ ) y tres fuentes orgánicas (control, vermicompost enriquecido con termofosfato yoorin y estiércol de aves de corral). Agregar estiércol de aves de corral a sustratos comerciales causa efectos negativos sobre la precocidad y la emergencia. Carolina ${ }^{\circledR}$ es un sustrato adecuado para producir plántulas de uchuva sin necesidad de suplementos con fuentes orgánicas. Bioplant ${ }^{\circledR}$ se comporta más como un acondicionador de emergencia, que requiere suplementos con fuentes orgánicas (preferiblemente vermicompost). Las plántulas adecuadas para el trasplante se pueden obtener a los 47 días después de la siembra.

Palabras clave adicionales: fruta exótica; propagación de plantas; Solanaceae; boro; relación C/N.

Received for publication: 31-12-2018 Accepted for publication: 23-11-2020

INTRODUCTION

Physalis peruviana (L.) fruits are exotic in terms of their appearance, taste, medicinal properties and nutritional value (Rufato et al., 2008; Puente et al., 2011; Lima et al., 2013; Çakir et al., 2014; El-Beltagi et al., 2019). This fruit is commonly called uchuva (Spanish), cape gooseberry, goldenberry or simply physalis (Muniz et al., 2011; Fischer et al., 2014).

The origin center for $P$. peruviana is located between the Peruvian and Ecuadorian Andes (Morton and Russel, 1954). It is a perennial and semi-evergreen shrub with indeterminate growth (Fischer and Melgarejo, 2020).

Cultivation in Colombia began in 1985 (Muniz et al., 2014). The cape gooseberry currently plays an important role in the country's export market, following bananas (Fischer et al., 2014). Most of the cape gooseberry supply in Brazil is imported from Colombia, complementing production on small plantations in Santa Catarina, Rio Grande do Sul, Minas Gerais and São Paulo (Rufato et al., 2008; Lima et al., 2009; Muniz et al., 2011; Rodrigues et al., 2012; Betemps et al., 2014).

Cape gooseberry production in Brazil presents an excellent alternative for small and medium producers because of the high added value of fresh fruits (98$150 \mathrm{R} \$ / \mathrm{kg}$ or $25.42-38.90 \mathrm{US} \$ / \mathrm{kg}$ ) and ease of cultivation. Production could transform this country from importer to exporter in a short period of time (Rufato et al., 2008).
Success in establishing new crops depends primarily from the propagation material. The cape gooseberry is propagated mainly with seeds (Muniz et al., 2014; Fischer et al., 2014), which is a cheap and efficient method because seeds have high, rapid germination (72.50\% at 7 days after sowing (DAS); $82.50 \%$ at 21 DAS) (Melo et al., 2015). However, obtaining seedlings takes a long time, around 2 months (Miranda, 2005), which increases the cost of seedlings for producers and nurseries.

The production of quality seedlings depends on several factors associated with the substrate composition (porosity, air and water retention, and electrical conductivity), nutritional supplementation (macronutrients and micronutrients), containers (volume, shape, cost), irrigation (frequency, quantity and water quality) and environment (temperature, humidity, photoperiod, radiation) (Villa et al., 2018; Reyes et al., 2019; Roveda-Hoyos and Moreno-Fonseca, 2019; Marchioretto et al., 2020). There are several substrate recommendations for cape gooseberries: washed sand, charred rice husks, turbid, Brazilian coco peat and mycorrhizae are the more common ones (Miranda, 2005; Díaz et al., 2010). Organic sources, such as manure and vermicompost, are excellent alternatives from the environmental and phytotechnical points of view (Inácio and Miller, 2009).

The objective of this study was to determine the effect of commercial substrates and organic sources on the production of cape gooseberry seedlings. 


\section{MATERIALS AND METHODS}

The cape gooseberry seeds came from plants in the germplasm bank of UDESC (Universidade Estadual de Santa Catarina), at Lages, State of Santa Catarina (Brazil). The seeds were then kept in a cold chamber $\left(5^{\circ} \mathrm{C}\right)$.

The design was completely randomized with a $2 \times 3$ factorial scheme using two commercial substrates (Carolina ${ }^{\circledR}$ - Carolina Soil Company, Santa Cruz do Sul/Rio Grande do Sul/Brazil; Bioplant ${ }^{\circledR}$ - Bioplant Agrícola Company, Nova Ponte - Minas Gerais/Brazil) and three organic sources (none, vermicompost enriched with yoorin thermophosphate (Guimarães et al., 2017) and poultry manure).

The physical and chemical characterization of the organic compounds is shown in table 1.

Table 1. Physical and chemical characterization of organic sources for substrates in the production of cape gooseberry seedlings.

\begin{tabular}{|c|c|c|}
\hline Parameter & Poultry manure & Vermicompost \\
\hline$N\left(g ~ k g^{-1}\right)$ & 28 & 8.2 \\
\hline $\mathrm{P}_{2} \mathrm{O}_{5}\left(\mathrm{~g} \mathrm{~kg}^{-1}\right)$ & 65 & 76 \\
\hline $\mathrm{K}_{2} \mathrm{O}\left(\mathrm{g} \mathrm{kg}^{-1}\right)$ & 30 & 5.5 \\
\hline $\mathrm{Ca}\left(\mathrm{g} \mathrm{kg}^{-1}\right)$ & 105 & 82 \\
\hline $\operatorname{Mg}\left(\mathrm{g} \mathrm{kg}^{-1}\right)$ & 10 & 37 \\
\hline Sulfur $\left(\mathrm{g} \mathrm{kg}^{-1}\right)$ & 4 & 2.2 \\
\hline Copper $\left(\mathrm{mg} \mathrm{kg}^{-1}\right)$ & 90 & 310 \\
\hline Iron $\left(\mathrm{mg} \mathrm{kg}^{-1}\right)$ & 13200 & 88500 \\
\hline Manganese $\left(\mathrm{mg} \mathrm{kg}^{-1}\right)$ & 800 & 360 \\
\hline Zinc $\left(\mathrm{mg} \mathrm{kg}^{-1}\right)$ & 500 & 2500 \\
\hline Boron $\left(\mathrm{mg} \mathrm{kg}^{-1}\right)$ & 480 & 400 \\
\hline Organic matter $\left(\mathrm{g} \mathrm{kg}^{-1}\right)$ & 415 & 120 \\
\hline Humidity $\left(\mathrm{g} \mathrm{kg}^{-1}\right)$ & 95 & 280 \\
\hline Mineral material $\left(\mathrm{g} \mathrm{kg}^{-1}\right)$ & 490 & 600 \\
\hline $\mathrm{pH}$ & 8.6 & 6.87 \\
\hline C/N Ratio & 9.5 & 11.8 \\
\hline Organic matter (\%Dry matter) & 45.9 & 16.7 \\
\hline Electrical conductivity $\left(\mathrm{mS} \mathrm{cm}^{-1}\right)$ & 8.01 & 2.78 \\
\hline Apparent density $\left(\mathrm{g} \mathrm{mL}^{-1}\right)$ & 0.54 & 1.29 \\
\hline Real density $\left(\mathrm{g} \mathrm{mL}^{-1}\right)$ & 1.85 & 1.9 \\
\hline Porosity (\%) & 70.8 & 32.1 \\
\hline
\end{tabular}

The treatments with commercial and organic sources used a $9 / 1$ ratio $(90 \%$ commercial substrate and $10 \%$ organic source). The commercial and composite substrates underwent a physicochemical analysis to determine $\mathrm{N}, \mathrm{P}_{2} \mathrm{O}_{5}$ (colorimetry with molybdate), $\mathrm{K}_{2} \mathrm{O}$ (flame photometry), $\mathrm{Ca}$ and $\mathrm{Mg}$ (atomic absorption), $\mathrm{S}$ (turbidimetry), $\mathrm{Cu}, \mathrm{Fe}, \mathrm{Zn}$ and $\mathrm{Mn}$ (atomic absorption), B (colorimetry with azomethine), organic matter, moisture, mineral matter and $\mathrm{pH}$ (potentiometry), $\mathrm{C} / \mathrm{N}$, organic matter (\% dry matter), electrical conductivity, real density and apparent density.

The seeds were sown in Styrofoam trays with 128 cells $\left(40 \mathrm{~cm}^{3} /\right.$ cell) filled with different combinations of commercial substrate and organic sources. Two seeds were placed in each cell. Six replicates of 36 seeds were used.

The trays were kept in a protected environment (greenhouse). A thermo-hygrometer data logger (AK172) was installed one and a half meters above the greenhouse floor. Daily climatic data, namely temperature (minimum, maximum, average) and relative humidity (mean), were collected. The thermal amplitude and the accumulated degree-days (ADD) were calculated. The ADD values were calculated with an equation adapted from McMaster and Wilhelm (1997) (Eq. 1)

$$
\begin{gathered}
A D D=\sum_{i=1}^{n}(T i-B t) \\
i=1
\end{gathered}
$$

where, $A D D$ is the accumulated degree-days or accumulated thermal sum in ${ }^{\circ} \mathrm{C}, T i$ is the average daily temperature in ${ }^{\circ} \mathrm{C}, \mathrm{Bt}$ is the base temperature $\left(6.3^{\circ}\right.$ C) (Salazar et al., 2008), $n$ is the number of days and $i$ is the day.

Seedling emergence was evaluated at 5, 8, 12, 16 and 21 DAS to calculate the emergence rate (Maguire, 1962). Seedling thinning was carried out during the emergence evaluation period, leaving only 1 seedling per cell.

A seedling growth analysis was performed at 47 DAS. The following variables were obtained: shoot height $(\mathrm{cm})$, collecting diameter $(\mathrm{mm})$, number of leaves, chlorophyll content (Falker Chlorophyll Index, FCI), total dry weight (g), shoot dry weight (g), root dry weight (g), shoot/height ratio and Dickson quality index (Dickson et al. 1960).

Three seedlings were sampled in each repetition. The shoot height and the hypocotyl diameter were 
determined using a graduated ruler and a pachymeter, respectively. The chlorophyll content was estimated using a CFL1030 meter (Falker). The seedlings were conditioned in paper bags and subjected to the greenhouse method $\left(60^{\circ} \mathrm{C}, 72 \mathrm{~h}\right)$ (Benincasa, 2003) to determine the dry weight of the shoots, roots and total dry weight.

The F Test was used to determine significance in the effects of the treatments, with the mean "organic sources" and the interactions between the "organic sources" and "commercial substrates" compared with the Tukey test. A correlation analysis (Pearson) was carried out between the phytotechnical attributes (emergence and biometric) and the physicochemical composition of the substrates.

\section{RESULTS AND DISCUSSION}

Emergence - The cape gooseberry seedling emergence began 8 DAS. This period was shorter than most seedling production systems in Colombia, where emergence onset occurs from 10 to $15 \mathrm{~d}$. Precocity is associated with thermal conditions (Muniz et al., 2014). There were high diurnal temperatures (on average $28^{\circ} \mathrm{C}$ ) and low nocturnal temperatures (on average $21.7^{\circ} \mathrm{C}$ ), with a mean thermal amplitude of $16.7^{\circ} \mathrm{C}$ up to $8 \mathrm{DAS}$.

Adding poultry manure to the commercial substrates had deleterious effects on the precocity and emergence viability (Fig. 1). Similar results have also been

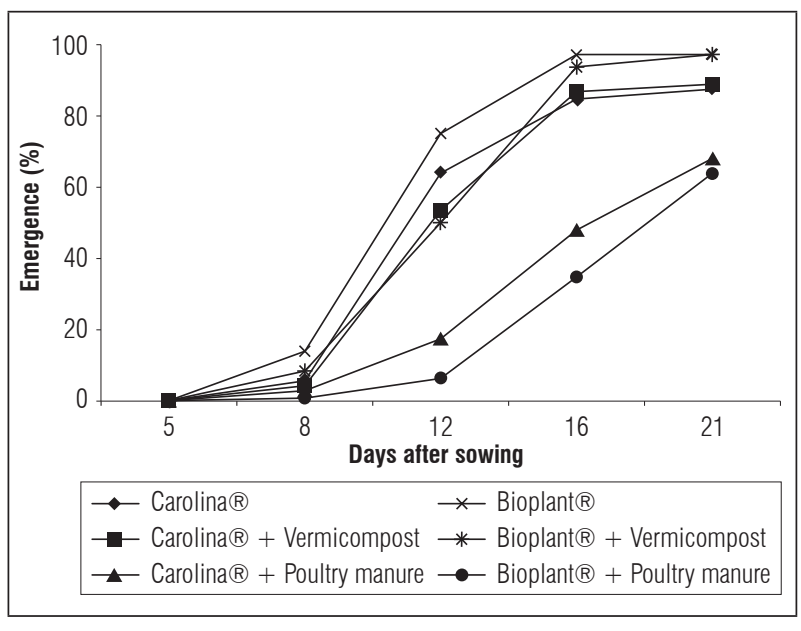

Figure 1. Evolution of cape gooseberry seedling emergence with different commercial substrates and organic sources. reported for other species, namely Cassia siamea, Dolonix regia, Leucaena leucocephala, Mimosa caesalpiniafolia, Enterolobium cotortosilicum (De Lucena et al., 2004), Solanum lycopersicon, Cucurbita pepo, Capsicum annum (Medina et al., 2009), Tamarindus indica (Queiróz et al., 2011), Passiflora edulis (Brugnara, 2014), Lepidium sativus (Rombola et al., 2015) and Zea mays (Vozhdayev et al., 2015).

The substrates with poultry manure had four crucial characteristics that contributed to a low seedlingemergence: high nitrogen, potassium and sulfur levels and high electrical conductivity (values above 2.0 $\mathrm{mS} \mathrm{cm}{ }^{-1}$ ) (Tab. 2). These characteristics, along with the $\mathrm{C} / \mathrm{N}$ ratio, were negatively correlated with the emergence percentage and emergence rate (Tab. 3).

The high levels of nitrogen, potassium and sulfur caused an ionic imbalance, culminating in saline and osmotic stress (Parida and Das, 2005; Chan et al., 2008; Libra et al., 2011) with consequent root toxicity. In addition, water absorption must have been altered because of the osmotic potential change (Mokhele et al., 2012; Liu et al., 2014). Therefore, membrane functionality and enzymatic complexes were compromised, causing deficient and/or delayed root protrusion and aerial emission.

\section{Biometric attributes of cape gooseberry seedlings}

An interaction was observed between the factors "commercial substrates" and "organic sources" for the variables emergence speed index, number of leaves, total dry weight, root dry weight, shoot dry weight and Dickson quality index (Tab. 4). The other variables were considered relative to the means of each factor.

The commercial substrate Carolina ${ }^{\circledR}$ enabled cape gooseberry seedling growth with higher seedling biometric quality than with the substrate Bioplant ${ }^{\circledR}$ (Tab. 4 and 5). The differences were 67\% (height), $14 \%$ (hypocotyl diameter), 48\% (height/diameter ratio), 37\% (number of leaves), 17\% (chlorophyll content), 385\% (total dry weight), 700\% (root dry weight), 400\% (shoot dry weight) and 400\% (Dickson quality index).

The superiority of the Carolina ${ }^{\circledR}$ substrate was attributed to its higher nutritional content (nitrogen, phosphorus, calcium, magnesium and sulfur) and balance of physical characteristics (apparent density and 
Table 2. Physical and chemical composition of the substrates composed of commercial products and organic sources used in cape gooseberry seedling production. Car. - Carolina ${ }^{\circledR}$; Bio. - Bioplant ${ }^{\circledR}$; Vermi. - Vermicompost; Poultry M. - Poultry manure.

\begin{tabular}{|c|c|c|c|c|c|c|}
\hline & Car. & Bio. & Car. + Vermi. & Car. + Poultry M. & Bio. + Vermi. & Bio. + Poultry M. \\
\hline$N\left(g ~ k g^{-1}\right)$ & 9.2 & 9 & 8 & 14 & 8.2 & 15 \\
\hline $\mathrm{P}_{2} \mathrm{O}_{5}\left(\mathrm{~g} \mathrm{~kg}^{-1}\right)$ & 13.5 & 10.9 & 38 & 35 & 47 & 36 \\
\hline $\mathrm{K}_{2} \mathrm{O}\left(\mathrm{g} \mathrm{kg}^{-1}\right)$ & 4 & 4 & 6 & 14 & 6.5 & 12.5 \\
\hline Ca $\left(\mathrm{g} \mathrm{kg}^{-1}\right)$ & 12.7 & 8.6 & 38 & 55 & 36.5 & 35.4 \\
\hline $\left.\operatorname{Mg}\left(g_{k g}\right)^{-1}\right)$ & 61 & 11 & 40 & 42 & 16.3 & 11.4 \\
\hline Sulfur $\left(\mathrm{g} \mathrm{kg}^{-1}\right)$ & 2.6 & 2 & 2.8 & 3.5 & 1.7 & 3 \\
\hline Copper $\left(\mathrm{mg} \mathrm{kg}^{-1}\right)$ & 10 & 20 & 160 & 30 & 120 & 240 \\
\hline Iron $\left(\mathrm{mg} \mathrm{kg}^{-1}\right)$ & 29,290 & 22,100 & 55,000 & 23,400 & 43,200 & 22,200 \\
\hline Manganese $\left(\mathrm{mg} \mathrm{kg}^{-1}\right)$ & 260 & 430 & 1800 & 380 & 1500 & 600 \\
\hline Zinc $\left(\mathrm{mg} \mathrm{kg}^{-1}\right)$ & 70 & 70 & 1500 & 200 & 900 & 250 \\
\hline Boron (mg kg-1) & 500 & 600 & 500 & 450 & 600 & 550 \\
\hline Organic matter $\left(\mathrm{g} \mathrm{kg}^{-1}\right)$ & 290 & 350 & 220 & 290 & 280 & 315 \\
\hline Humidity $\left(\mathrm{g} \mathrm{kg}^{-1}\right)$ & 410 & 450 & 360 & 330 & 440 & 425 \\
\hline Mineral material $\left(\mathrm{g} \mathrm{kg}^{-1}\right)$ & 300 & 200 & 420 & 380 & 280 & 260 \\
\hline $\mathrm{pH}$ & 5.6 & 6.02 & 6.19 & 7.01 & 6.76 & 6.91 \\
\hline $\mathrm{C} / \mathrm{N}$ ratio & 31 & 41 & 24.9 & 17.9 & 35.4 & 21.2 \\
\hline Organic matter (\%Dry matter) & 49.2 & 63.6 & 34.4 & 43.3 & 50 & 54.8 \\
\hline Electrical conductivity $\left(\mathrm{mS} \mathrm{cm}^{-1}\right)$ & 1.72 & 1.09 & 1.78 & 2.67 & 1.81 & 2.91 \\
\hline Apparent density $\left(\mathrm{g} \mathrm{mL}^{-1}\right)$ & 0.18 & 0.37 & 0.33 & 0.25 & 0.49 & 0.4 \\
\hline Real density $\left(\mathrm{g} \mathrm{mL}^{-1}\right)$ & 0.57 & 1.1 & 1 & 0.73 & 1.35 & 1.3 \\
\hline Porosity (\%) & 68.4 & 66.4 & 67 & 65.7 & 63.7 & 69.2 \\
\hline
\end{tabular}

Table 3. Correlation matrix between emergence attributes and physicochemical composition of substrates used to produce cape gooseberry seedlings.

\begin{tabular}{|c|c|c|c|c|c|c|c|c|c|c|}
\cline { 2 - 11 } \multicolumn{1}{c|}{} & $8 \mathrm{E}$ & $12 \mathrm{E}$ & $16 \mathrm{E}$ & $21 \mathrm{E}$ & $\mathrm{ESI}$ & $\mathrm{N}$ & $\mathrm{K}_{2} \mathrm{O}$ & $\mathrm{S}$ & $\mathrm{C} / \mathrm{N}$ & $\mathrm{EC}$ \\
\hline $8 \mathrm{E}$ & 1 & & & & & & & & \\
\hline $12 \mathrm{E}$ & 0.804 & 1 & & & & & & & \\
\hline $16 \mathrm{E}$ & 0.836 & 0.967 & 1 & & & & & & & \\
\hline $21 \mathrm{E}$ & 0.777 & 0.968 & 0.983 & 1 & & & & & & \\
\hline $\mathrm{ESI}$ & 0.860 & 0.993 & 0.964 & 0.954 & 1 & & & & & \\
\hline $\mathrm{N}$ & -0.650 & $-0.972^{*}$ & $-0.916^{*}$ & $-0.933^{*}$ & $-0.939^{*}$ & 1 & & & & \\
\hline $\mathrm{K}_{2} \mathrm{O}$ & -0.717 & $-0.921^{*}$ & $-0.844^{*}$ & $-0.813^{*}$ & $-0.929^{*}$ & $0.906^{*}$ & 1 & & & \\
\hline $\mathrm{S}$ & -0.790 & -0.790 & $-0.883^{*}$ & -0.785 & -0.800 & 0.726 & 0.736 & 1 & \\
\hline $\mathrm{C} / \mathrm{N}$ & $0.935^{*}$ & $0.840^{*}$ & $0.883^{*}$ & 0.793 & $0.884^{*}$ & -0.724 & -0.833 & -0.924 & 1 & \\
\hline $\mathrm{EC}$ & $-0.893^{*}$ & $-0.951^{*}$ & $-0.892^{*}$ & $-0.872^{*}$ & $-0.976^{*}$ & 0.878 & 0.930 & 0.738 & -0.887 & 1 \\
\hline
\end{tabular}

$8 \mathrm{E}$ - 8E - Emergence 8 days after sowing (DAS); 12E - 12 DAS; $16 \mathrm{E}$ - 16 DAS; $21 \mathrm{E}$ - 21 DAS; ESI - Emergence speed index; N - Nitrogen $\left(\mathrm{g} \mathrm{kg}^{-1}\right) ; \mathrm{K}_{2} \mathrm{O}-\mathrm{Potassium}$ $\left(\mathrm{g} \mathrm{kg}^{-1}\right)$; $\mathrm{S}$ - Sulfur $\left(\mathrm{g} \mathrm{kg}^{-1}\right)$; C/N - C/N ratio; EC - Electrical conductivity $\left(\mathrm{mS} \mathrm{cm}^{-1}\right) .{ }^{*}$ - significant $(P<0.05)$. 
Table 4. Seedling emergence at 21 days after sowing (E21), emergence speed index (ESI), height (H), hypocotyl diameter (HD), diameter/shoot height ratio (DHR), number of leaves (NL), total dry weight (TDW), root dry weight (RDW), shoot dry weight (SDW), chlorophyll content (CHL) and Dickson quality index (DOI) of cape gooseberry seedlings produced with different commercial substrates and organic sources.

\begin{tabular}{|c|c|c|c|c|c|c|c|c|c|c|c|}
\hline Treatment & $\begin{array}{l}\text { E21 } \\
(\%)\end{array}$ & ESI & $\begin{array}{c}\mathrm{H} \\
\text { (cm/ } \\
\text { plant) }\end{array}$ & $\begin{array}{c}\mathrm{HD} \\
\text { (mm/ } \\
\text { plant) }\end{array}$ & DHR & $\begin{array}{c}\text { NL } \\
\text { (leaves/ } \\
\text { plant) }\end{array}$ & $\begin{array}{c}\mathrm{CHL} \\
\text { (FCI) }\end{array}$ & $\begin{array}{l}\text { TDW } \\
\text { (mg/ } \\
\text { plant) }\end{array}$ & $\begin{array}{l}\text { RDW } \\
\text { (mg/ } \\
\text { plant) }\end{array}$ & $\begin{array}{l}\text { SDW } \\
\text { (mg/ } \\
\text { plant) }\end{array}$ & DOI \\
\hline \multicolumn{12}{|c|}{ Substrate (Subs) } \\
\hline Carolina $^{\circledR}$ & 92.12 & 7.57 & 7.38 & 2.24 & 3.27 & 7.52 & 29.77 & 0.26 & 0.05 & 0.20 & 0.03 \\
\hline Bioplant ${ }^{\circledR}$ & 92.59 & 7.84 & 4.41 & 1.96 & 2.20 & 6.68 & 25.38 & 0.16 & 0.03 & 0.13 & 0.02 \\
\hline Test $\mathrm{F}$ & $0.04^{\mathrm{NS}}$ & $1.53^{\mathrm{NS}}$ & $56.09 * *$ & $14.14^{* *}$ & $74.60^{* *}$ & $9.93^{* *}$ & $15.54^{* *}$ & $23.27^{* *}$ & $12.78^{* *}$ & $15.61^{* *}$ & $4.20^{* *}$ \\
\hline \multicolumn{12}{|c|}{ Organic source (OS) } \\
\hline Control & 95.83 a & 9.07 a & $4.66 \mathrm{~b}$ & $1.93 \mathrm{~b}$ & $2.34 \mathrm{~b}$ & $6.38 b$ & $25.82 b$ & $0.17 b$ & $0.04 b$ & $0.12 b$ & $\begin{array}{c}0.03 \\
a b\end{array}$ \\
\hline Vermicompost & $97.22 \mathrm{a}$ & 8.58 a & $6.15 a$ & $2.25 \mathrm{a}$ & $2.70 \mathrm{~b}$ & 7.33 a & $27.00 a b$ & $0.20 a b$ & $0.06 \mathrm{a}$ & $0.14 b$ & $0.04 \mathrm{a}$ \\
\hline Poultry manure & $84.02 b$ & $5.47 b$ & $6.86 \mathrm{a}$ & $2.13 \mathrm{ab}$ & $3.16 \mathrm{a}$ & $7.59 \mathrm{a}$ & $29.90 \mathrm{a}$ & $0.27 \mathrm{a}$ & $0.03 \mathrm{~b}$ & $0.23 \mathrm{a}$ & $0.02 \mathrm{~b}$ \\
\hline Test F & $15.28 * *$ & $100.33^{* *}$ & $10.69 * *$ & $6.57^{* *}$ & $14.48^{* *}$ & $6.92^{* *}$ & $4.72^{*}$ & $7.02^{* *}$ & $11.12^{* *}$ & $12.82^{* *}$ & $6.15^{* *}$ \\
\hline Test F (Subs $\times 0$ S) & $3.13^{\mathrm{NS}}$ & $7.30 * *$ & $1.04^{\mathrm{NS}}$ & $1.92^{\mathrm{NS}}$ & $3.18 \mathrm{~ns}$ & $4.44^{*}$ & $2.15^{\mathrm{NS}}$ & $9.08^{* *}$ & $7.76^{* *}$ & $10.41^{* *}$ & $7.77^{* *}$ \\
\hline
\end{tabular}

${ }^{*}$ significant $(P<0.05) ;{ }^{* *}$ significant $(P<0.01)$; ${ }^{\text {Ns }}$ non-significant. Means followed by the same letter do not differ according to Tukey's test $(P>0.05)$.

Table 5. Emergence speed index (ESI), number of leaves (NL), total dry weight (TDW), dry matter mass (RDW), shoot dry weight (SDW) and Dickson quality index (DOI) of cape gooseberry seedlings produced with different commercial substrates and organic sources.

\begin{tabular}{|c|c|c|c|}
\hline & Control & Vermicompost & Poultry manure \\
\hline \multicolumn{4}{|c|}{ ESI } \\
\hline Carolina $^{\circledR}$ & 8.51 bA & 8.26 aA & $5.92 \mathrm{aB}$ \\
\hline Bioplant $^{\circledR}$ & $9.62 \mathrm{aA}$ & $8.89 \mathrm{aA}$ & $5.02 \mathrm{bB}$ \\
\hline \multicolumn{4}{|c|}{$\mathrm{NL}$} \\
\hline Carolina $^{\circledR}$ & $7.38 \mathrm{aA}$ & $7.56 \mathrm{aA}$ & 7.63 aA \\
\hline Bioplant $^{\circledR}$ & $5.38 \mathrm{bB}$ & $7.11 \mathrm{aA}$ & $7.55 \mathrm{aA}$ \\
\hline \multicolumn{4}{|c|}{ TDW } \\
\hline Carolina $^{\circledR}$ & $0.27 \mathrm{aAB}$ & $0.20 \mathrm{aB}$ & $0.32 \mathrm{aA}$ \\
\hline Bioplant ${ }^{\circledR}$ & $0.07 \mathrm{bB}$ & $0.21 \mathrm{aA}$ & $0.21 \mathrm{bA}$ \\
\hline \multicolumn{4}{|c|}{ RDW } \\
\hline Carolina $^{\circledR}$ & $0.07 \mathrm{aA}$ & 0.07 aA & $0.03 \mathrm{aB}$ \\
\hline Bioplant ${ }^{\circledR}$ & $0.01 \mathrm{bB}$ & $0.06 \mathrm{aA}$ & $0.03 \mathrm{aB}$ \\
\hline \multicolumn{4}{|c|}{ SDW } \\
\hline Carolina $^{\circledR}$ & $0.20 \mathrm{aA}$ & $0.12 \mathrm{aB}$ & 0.29 aA \\
\hline Bioplant ${ }^{\circledR}$ & $0.05 \mathrm{bB}$ & $0.17 \mathrm{aA}$ & $0.17 \mathrm{bA}$ \\
\hline \multicolumn{4}{|c|}{$\mathrm{DOI}$} \\
\hline Carolina $^{\circledR}$ & $0.04 \mathrm{aA}$ & $0.04 \mathrm{aA}$ & $0.02 \mathrm{aB}$ \\
\hline Bioplant $^{\circledR}$ & $0.01 \mathrm{bB}$ & 0.04 aA & $0.02 \mathrm{aAB}$ \\
\hline
\end{tabular}

Means followed by the same lowercase letter in a column and the same uppercase letter in a row do not differ according to Tukey's test $(P>0.05)$. 
actual density) (Tab. 2). Cape gooseberry seeds are very small and quickly deplete their reserves, so the substrate must provide necessary nutrients and satisfactory aeration conditions for seedling growth and development (Melo et al., 2015). The ideal substrate provides the conditions needed rapid and uniform emergence and vigorous, proportional development (Ferreira et al., 2009). The Bioplant ${ }^{\circledR}$ substrate acts more like an emergence conditioner. Other studies have reported a lack of adequate physical and chemical conditions for seedling production in other species when fertilization supplementation is primordial (Almeida et al., 2014). Dutra et al. (2012) reported that Bioplant ${ }^{\circledR}$ led to the formation of copaiba seedlings (Copaifera langsdorffii) that were deficit in the accumulation of leaf and total dry weight. Ferreira et al. (2009) described this substrate as causing asymmetry between the shoot and root dry weights in cupuaçu seedlings (Theobroma grandiflorum).

The fundamental physical and chemical attributes for the growth of cape gooseberry seedlings are: moisture, mineral matter, $\mathrm{C} / \mathrm{N}$ ratio, organic matter and boron and sulfur contents (Tab. 6). Only these attributes presented a correlation with the biometric attributes.

The boron content and humidity were negatively correlated with the shoot height, height-diameter ratio, and chlorophyll content (Tab. 6). Cape gooseberry seedlings may not tolerant inadequate boron levels in substrates. This tolerance depends on the transport speed from the roots to the shoot (Salvador et al., 2003). No symptoms of boron toxicity were observed in the cape gooseberry seedlings. Other studies should be conducted to determine the nutritional requirements for boron and other nutrients in the seedling production phase.

The $\mathrm{C} / \mathrm{N}$ ratio had the opposite effect on the height, diameter/height ratio, number of leaves and chlorophyll content (Tab. 6). A substrate with a high $\mathrm{C} / \mathrm{N}$ ratio has low degradability, low nutrient availability and, depending on the seedling production period, deficient nitrogen (Maeda et al., 2007). Nitrogen is a key component of several molecules that are essential

Table 6. Correlation between emergence speed and biometric attributes and the physical and chemical composition of composite substrates in cape gooseberry seedling production.

\begin{tabular}{|c|c|c|c|c|c|c|c|c|c|c|c|c|c|c|c|c|}
\hline & ESI & SH & $\mathrm{HD}$ & DHR & NL & CHLO & TDW & SDW & DQI & S & B & $\mathrm{OM}$ & Hum & MM & $\mathrm{C} / \mathrm{N}$ & $\begin{array}{l}\mathrm{OM} \\
(\%)\end{array}$ \\
\hline ESI & 1 & & & & & & & & & & & & & & & \\
\hline SH & -0.511 & 1 & & & & & & & & & & & & & & \\
\hline HD & -0.311 & $0.856^{*}$ & 1 & & & & & & & & & & & & & \\
\hline DHR & -0.553 & $0.983^{*}$ & 0.758 & 1 & & & & & & & & & & & & \\
\hline NL & -0.634 & $0.871^{*}$ & $0.857^{*}$ & $0.852^{*}$ & 1 & & & & & & & & & & & \\
\hline CHLO & -0.674 & $0.875^{*}$ & 0.746 & $0.844^{*}$ & 0.745 & 1 & & & & & & & & & & \\
\hline TDW & -0.554 & $0.873^{*}$ & 0.620 & $0.932^{*}$ & $0.858^{*}$ & 0.643 & 1 & & & & & & & & & \\
\hline SDW & -0.616 & 0.761 & 0.421 & $0.852^{*}$ & 0.740 & 0.536 & $0.960^{*}$ & 1 & & & & & & & & \\
\hline DOI & 0.264 & 0.425 & 0.689 & 0.353 & 0.558 & 0.119 & 0.400 & 0.181 & 1 & & & & & & & \\
\hline S & -0.800 & 0.781 & 0.493 & 0.806 & 0.621 & $0.930^{*}$ & 0.652 & 0.642 & -0.182 & 1 & & & & & & \\
\hline B & 0.484 & $-0.925^{*}$ & -0.648 & $-0.943^{*}$ & -0.670 & $-0.891^{*}$ & -0.792 & -0.714 & $-0.166^{*}$ & -0.875 & 1 & & & & & \\
\hline $\mathrm{OM}$ & -0.007 & -0.701 & $-0.940^{*}$ & -0.575 & -0.667 & -0.521 & -0.428 & -0.214 & -0.785 & -0.219 & 0.468 & 1 & & & & \\
\hline Hum & 0.434 & $-0.908^{*}$ & -0.700 & $-0.885^{*}$ & -0.618 & $-0.841^{*}$ & -0.689 & -0.633 & -0.135 & -0.810 & $0.921^{*}$ & 0.589 & 1 & & & \\
\hline $\mathrm{MM}$ & -0.252 & $0.908^{*}$ & $0.913^{*}$ & $0.828^{*}$ & 0.719 & 0.773 & 0.633 & 0.487 & 0.497 & 0.593 & -0.792 & $-0.880^{*}$ & $-0.903^{*}$ & 1 & & \\
\hline $\mathrm{C} / \mathrm{N}$ & $0.884^{*}$ & $-0.837^{*}$ & -0.664 & $-0.836^{*}$ & $-0.822^{*}$ & $-0.908^{*}$ & -0.737 & -0.712 & -0.021 & $-0.924^{*}$ & 0.784 & 0.396 & 0.777 & -0.669 & 1 & \\
\hline $\begin{array}{l}\mathrm{OM} \\
(\%)\end{array}$ & 0.176 & $-0.868^{*}$ & $-0.958^{*}$ & -0.772 & -0.747 & -0.700 & -0.603 & -0.426 & -0.644 & -0.469 & 0.696 & $0.953^{*}$ & 0.804 & $-0.981 *$ & 0.595 & 1 \\
\hline
\end{tabular}

* - significant $(P<0.05)$. ESI - Emergence speed index; SH - Shoot height; HD - Hypocotyl diameter ; DHR - Diameter/height ratio; NL - Number of leaves; CHLO - Chlorophyll; TDW - Total dry weight; SDW - Shoot dry weight; DOI - Dickson quality index; S - Sulfur; B - Boron; OM - Organic matter; Hum - Humidity; MM Mineral matter; C/N - C/N ratio; OM (\%) - Organic matter. 
for the primary and secondary metabolism of plants (proteins, nucleic acids, hormones, chlorophyll and vitamins). Therefore, an unbalanced supply of this nutrient impacts several biosynthetic pathways and consequently the growth and allocation of dry weight (Xu et al., 2012).

The seedlings were ready for transplant at 47 DAS, when over four true leaves had fully expanded (Tab. 5). The $\mathrm{ADD}$ was $1,054^{\circ} \mathrm{C}$. In Colombia, the average period for obtaining transplanted seedlings is 60 d (Angulo, 2005). In addition to the delayed early emergence (10-15 DAS), seeds are sown in trays, and seedlings are transplanted to $1 \mathrm{~L}$ plastic bags 15 days after emergence, where they stay for another $30 \mathrm{~d}$ (Miranda, 2005). Transplant suitability encompasses criteria related to shoot height $(15-20 \mathrm{~cm})$, hypocotyl diameter $(0.5 \mathrm{~cm})$ and number of leaves (3-4) (Miranda, 2005; Angulo, 2005). The seedlings produced only with the Bioplant ${ }^{\circledR}$ substrate had on average of 5.38 leaves at 47 DAS (Tab. 5) but they were not suitable for transplant because of a low height, minimum accumulation of dry weight and low quality, as indicated by the Dickson index (Tab. 4). Seedlings may not have to reach a height of 15 to $20 \mathrm{~cm}$ because several other Solanaceae (tomato, eggplant, pepper) species are successfully transplanted with lower heights. Therefore, the transplanting criteria need to be better established, based on a combination of attributes related to climatic conditions (degree-days), biometric attributes and local productive systems. The production of cape gooseberry seedlings with the Carolina ${ }^{\circledR}$ substrate did not require supplementation with organic sources. An alternative for supplementation in the Bioplant ${ }^{\circledR}$ substrate is vermicompost enriched with yoorin thermophosphate, a material with excellent chemical and physical attributes (Tab. 1). The use of poultry manure must be carefully mediated because of deleterious effects on emergence.

\section{CONCLUSION}

Carolina ${ }^{\circledR}$ is a suitable substrate for the production of cape gooseberry seedlings without the need for organic-source supplementation. Bioplant ${ }^{\circledR}$ acts more like an emergence conditioner that requires supplementation with organic source (preferably with vermicompost).

Seedlings that are suitable for transplant can be obtained at 47 DAS.
Conflict of interests: The manuscript was prepared and reviewed with the participation of the authors, who declare that there exists no conflict of interest that puts at risk the validity of the presented results.

\section{BIBLIOGRAPHIC REFERENCES}

Almeida, M.O., M.C.M Cruz, G.D.M. Castro, and M.C.P. Fagundes. 2014. Crescimento e absorção de nutrientes por mudas de maracujazeiro-amarelo em função substrato e da adubação nitrogenada. Agraria 9(2), 180-185. Doi: 10.5039/agraria.v9i2a3593

Angulo, R. 2005. Crecimento, desarollo y producción de la uchuva en condiciones de invernadero y campo abierto. pp. 111-128. In: Fischer, G., D. Miranda, W. Piedrahita, and J. Romero (eds.). Avances en cultivo, poscosecha y exportación de la uchuva (Physalis peruviana L.) en Colombia. Universidad Nacional de Colombia, Bogota.

Benincasa, M.M.P. 2003. Análise de crescimento de plantas: noções básicas. FUNEP, Jaboticabal, Brazil.

Betemps, D.L., J.C. Fachinello, C.S.M. Lima, S.P. Galarça, A.R. Rufato. 2014. Época de semeadura, fenologia e crescimento de plantas de físalis no sul do Brasil. Rev. Bras. Frutic. 36(1), 179-185. Doi: 10.1590/0100-2945-292/13

Brugnara, E.C. 2014. Cama de aviário em substratos para mudas de maracujazeiro-amarelo. Rev. Bras. Agroecol. 9(3), 21-30

Çakir, O., M. Pekmek, E. Çepni, B. Andar, and K. Fídan. 2014. Evaluation of biological activities of Physalis peruviana extracts and expression of $\mathrm{Bcl}-2$ - genes in HeLa cells. Food Sci. Technol. 34(2), 422-430. Doi: $10.1590 /$ fst. 2014.0060

Chan, K.Y., L. Van Zwieten, I. Mezaros, A. Downie, and S. Joseph. 2008. Using poultry litter biochars as soil amendments. Aust. J. Soil Res. 46(5), 437-444. Doi: 10.1071/SR08036

De Lucena, A.M.A., A. Micheline, F. Costa Xavier, H. Silva, and H.O. Guerra Carvalho. 2004. Germinação de essências florestais em substratos fertilizados com matéria orgânica. Rev. Biol. Ciênc. Terra 4(13), 27-33.

Díaz, L., G. Fischer, S. Pulido. 2010. La fibra de coco como sustituto de la turba en la obtención de plántulas de uchuva (Physalis peruviana L.). Rev. Colomb. Cienc. Hortic. 4(2), 153-162. Doi: 10.17584/ rcch.2010v4i2.1236

Dickson, A., A.L. Leaf, and J.F. Hosner. 1960. Quality appraisal of white spruce and white pine seedling stock in nurseries. Forest Chron. 36(1), 10-13. Doi: 10.5558/ tfc36010-1

Dutra, T.R., P.H. Grazziotti, R.C. Santana, and M.D. Massad. 2012. Desenvolvimento inicial de mudas de copaíba sob diferentes níveis de sombreamento e 
substratos. Rev Cienc Agron. 43(2), 321-329. Doi: 10.1590/S1806-66902012000200015

El-Beltagi, H.S., H.I. Mohamed, G. Safwat, M. Gamal, and B.M.H. Megahed. 2019. Chemical composition and biological activity of Physalis peruviana L. Gesunde Pflanzen 71, 113-122. Doi: 10.1007/s10343-019-00456-8

Ferreira, M.G.R., R.B. Rocha, E.P. Gonçalves, E.U. Alves, and G.D. Ribeiro. 2009. Influência do substrato no crescimento de mudas de cupuaçu (Theobroma grandiflorum Schum.). Acta Sci. Agron. 31(4), 677-681. Doi: 10.4025/actasciagron.v31i4.3092

Fischer, G., P.J. Almanza-Merchán, P. Miranda. 2014. Importancia y cultivo de la uchuva (Physalis peruviana L.). Rev. Bras. Frutic. 36(1), 1-15. Doi: 10.1590/0100-2945-441/13

Fischer, G. and L.M. Melgarejo. 2020. The ecophysiology of cape gooseberry (Physalis peruviana L.) - an Andean fruit crop. A review. Rev. Colomb. Cienc. Hortic. 14(1), 76-89. Doi: 10.17584/rcch.2020v14i1.10893

Guimarães, R.N., V. Damin, P.M. Fernandes, W.M. Leandro, A.P.C. Melo, and J. Rosa, 2017. Production of phosphate biofertilizer through composting and vermicomposting process. Comun. Sci. 8(3), 432-443. Doi: 10.14295/cs.v8i3.1004

Inácio, C.T. and P.R.M. Miller. 2009. Compostagem: Ciência e prática para gestão de resíduos orgânicos. Embrapa Solos, Rio de Janeiro, Brazil.

Libra, J.A., K.S. Ro, C. Kammann, A. Funke, N.D. Berge, Y. Neubauer, M.M. Titirici, C. Fuhner, O. Bens, J. Kern, and K.H. Emmerich. 2011. Hydrothermal carbonization of biomass residuals: a comparative review of the chemistry, processes and applications of wet and dry pyrolysis. Biofuels 2(1), 89-124. Doi: 10.4155/bfs.10.81

Lima, C.S.M., R. Manica-Berto, S.J.P. Silva, D.L. Betemps, and A.R. Rufato. 2009. Custos de implantação e condução de pomar de Physalis na região sul. Rev. Ceres 56(5), 555-561.

Lima, C.S.M., J. Severo, S.B. De Andrade, L.B. Affonso, C.V. Rombaldi, and A.R. Rufato. 2013. Qualidade pós-colheita de Physalis sob temperatura ambiente e refrigeração. Rev. Ceres, 60(3), 311-317. Doi: 10.1590/ S0034-737X2013000300002

Liu, Y., Q. Wang, Y. Zhang, J. Cui, G. Chen, B. Xie, C. Wu, H. Liu. 2014. Synergistic and antagonistic effects of salinity and $\mathrm{pH}$ on germination in switchgrass (Panicum virgatum L.). Plos One 9(1), e85282. Doi: 10.1371/ journal.pone.0085282

Maeda, S., R.A. Dedecek, R.B. Agostini, G.C. Andrade, and H.D. Da silva. 2007. Caracterização de substratos para produção de mudas de espécies florestais elaborados a partir de resíduos orgânicos. Pesqui. Florest. Bras. 27(54), 97-104.

Maguire, J.D. 1962. Speeds of germination-aid selection and evaluation for seedling emergence and vigor. Crop Sci. 2(1), 176-177. Doi: 10.2135/ cropsci1962.0011183X000200020033x

Marchioretto, L.D., A.D. Rossi, and E.D. Conte. 2020. Chemical root pruning improves quality and nutrient uptake of cape gooseberry (Physalis peruviana) seedlings. Sci Hortic 261(2), 108948. Doi: 10.1016/j. scienta.2019.108948

McMaster, G.S. and W.W. Wilhelm. 1997. Growing degree-days: one equation, two interpretations. Agric. For. Meteorol. 87(4), 291-300. Doi: 10.1016/ S0168-1923(97)00027-0

Medina, E., C. Paredes, M.A. Pérez-Murcia, and R.M. Bustamante. 2009. Spent mushroom substrates as component of growing media for germination and growth of horticultural plants. Bioresour. Technol. 100(18), 4227-4232. Doi: 10.1016/j.biortech.2009.03.055

Melo, A.P.C., C.M. Silva-Neto, A. Seleguini, and P.M. Fernandes. 2015. Does fruit cooling and seed film coating affect the germination potential of physalis? Sci. Agropecu. 6(4), 325-328.

Miranda, D. 2005. Criterios para el establecimiento, los sistemas de cultivo, el tutorado y la poda de la uchuva. pp. 29-54. In: Fischer, G., D. Miranda, W. Piedrahíta, and J. Romero (eds.). Avances en cultivo, poscosecha y exportación de la uchuva (Physalis peruviana L.) en Colombia. Universidad Nacional de Colombia, Bogota, DC.

Mokhele, B., X. Zhan, G. Yang, and X. Zhang. 2012. Nitrogen assimilation in crop plants and its affecting factors. Can. J. Plant. Sci. 92(3), 399-405. Doi: 10.4141/ cjps2011-135

Morton, J.F. and O.S. Roussel. 1954. The cape gooseberry and the mexican husk tomato. Proc. Fla. State Hortic. Soc. 67, 261-266.

Muniz, J., A.A. Kretzschamar, L. Rufato, T.R. Pelizza, T. Marchi, A.E. Duarte, A.P.F. Lima, and F. Garanhani. 2011. Sistemas de condução para o cultivo de Physalis no planalto catarinense. Rev. Bras. Frutic. 33(3), 830838. Doi: 10.1590/S0100-29452011005000083

Muniz, J., A.A. Kretzschamar, L. Rufato, T.R. Pelizza, A.R. Rufato, and T.A. Macedo. 2014. General aspects of physalis cultivation. Cienc. Rural 44(6), 964-970. Doi: 10.1590/S0103-84782014005000006

Parida, A.K. and A.B. Das. 2005. Salt tolerance and salinity effects on plants: a review. Ecotoxicol. Environ. Saf. 60(3), 324-349. Doi: 10.1016/j.ecoenv.2004.06.010

Puente, L.A., C.A. Pínto-Muñoz, E.S. Castro, and M. Cortés. 2011. Physalis peruviana Linnaeus, the multiple properties of a highly functional fruit: A review. Food Res. Int. 44(7), 1733-1740. Doi: 10.1016/j. foodres.2010.09.034

Queiróz, J.M.O., A.C.V.L. Dantas, V.O. Almeida, and J.P. Barroso. 2011. Emergência de plântulas e crescimento inicial de tamarindeiro em diferentes substratos. Magistra 23(4), 221-227. 
Reyes, S.M.R., G.R. Hoyos, D.C. Ferreira Júnior, A.B. Cecílio Filho, and L.P. Moreno. 2019. Physiological response of Physalis peruviana L. seedlings inoculated with Funneliformis mosseae under drought stress. Rev. Ciênc. Agrár. 42(1), 171-180.

Rodrigues, F.A., E.S. Penoni, J.D.D. Soares, and M. Pasqual. 2012. Caracterização do ponto de colheita de Physalis peruviana L. na região de Lavras, MG. Biosci. J. 28(6), 862-867.

Rombola, A.G., G. Marisi, C. Torri, D. Fabbri, A. Buscaroli, M. Ghidotti, and A. Hornung. 2015. Relationships between chemical characteristics and phytotoxicity of biochar from poultry litter pyrolysis. J. Agric. Food Chem. 63(30), 6660-6667. Doi: 10.1021/acs. jafc. 5 b01540

Roveda-Hoyos, G. and L. Moreno-Fonseca. 2019. Physiological and antioxidant responses of cape gooseberry (Physalis peruviana L.) seedlings to phosphorus deficiency. Agron. Colomb. 37(1), 3-11. Doi: 10.15446/ agron.colomb.v37n1.65610

Rufato, L., A.R. Rufato, C. Schlemper, C.S.M. Lima, and A.A. Kretzschmar. 2008. Aspectos técnicos da cultura da physalis. CAV/UDESC-UFPel, Lages, Brazil.
Salazar, M.R., J.W. Jones, B. Chaves, A. Cooman, and G. Fischer. 2008. Base temperature and simulation model for nodes appearance in cape gooseberry (Physalis peruviana L.). Rev. Bras. Frutic. 30(4), 862-867. Doi: 10.1590/S0100-29452008000400004

Salvador, J.O., A. Moreira, E. Malavolta, and C.P. Cabral. 2003. Influência do boro e do manganês no crescimento e na composição mineral de mudas de goiabeira. Ciênc. Agrotec. 27(2), 325-331. Doi: 10.1590/ S1413-70542003000200011

Villa, F., D.F. da Silva, T.A. Peron, and E.J. Mezzalira. 2018. Initial development of Physalis seedlings in substrates and containers. Comun. Sci. 9(1), 50-57. Doi: 10.14295/cs.v9i1.1313

Vozhdayev, G.V., K.A. Spokas, J.S. Molde, S.M. Hellmann, B.M. Wood, and K.J. Valentas. 2015. Response of maize germination and growth to hydrothermal carbonization filtrate type and amount. Plant Soil 396(1), 127-136. Doi: 10.1007/s11104-015-2577-3

Xu, G., X. Fan, and A. Miller. 2012. Plant nitrogen assimilation and use efficiency. Annu. Rev. Plant Biol. 63(1), 153182. Doi: 10.1146/annurev-arplant-042811-105532 